\title{
A Study on the Training System of New Teachers in Korea
}

\author{
Soojung Park \\ Chungnam National University
}

\begin{abstract}
The new teacher's adaptation to teaching practice and improvement of working skills has been an ongoing task. There is no formal training system for new teachers in Korea. In Korea, public school teachers are considered national servant. If someone passes teacher employment test, he or she becomes a full-time regular teacher immediately. In order to solve new teacher's difficulty and to select unqualified teachers, introducing a probationary teacher system in Korea is needed. First, the plan is to expand teaching practicum in pre-service education, secondly, to introduce a probationary teacher system as the final stage of teacher employment test, and thirdly, to provide trainee education to newly hired teachers. The literature analysis and survey results revealed that the third measure is most realistic and that many teachers support it. To clarify this plan, the focus of the probationary teacher's system should be 'development of capabilities' rather than 'assessment' and the development and operation of a systemic and specific new teacher training program are needed.
\end{abstract}

Keywords: training system, new teachers, adaptation, teaching practice, pre-service education 